\title{
Erratum to: 3-Dimensional (3D) laparoscopy improves operating time in small spaces without impact on hemodynamics and psychomental stress parameters of the surgeon
}

\author{
Xiaoyan Feng ${ }^{1}$ - Anna Morandi ${ }^{1} \cdot$ Martin Boehne $^{2}$ - Tawan Imvised ${ }^{1}$. \\ Benno M. Ure ${ }^{1} \cdot$ Joachim F. Kuebler $^{1} \cdot$ Martin Lacher $^{1}$
}

Published online: 18 March 2015

(C) Springer Science+Business Media New York 2015

\section{Erratum to: Surg Endosc}

DOI 10.1007/s00464-015-4083-3

The XML metadata for the fifth author B. M. Ure was wrong resulting in an incorrect PubMed citation: M Ure B.

It should be Ure BM.

The online version of the original article can be found under doi:10.1007/s00464-015-4083-3.

Martin Lacher

lacher.martin@mh-hannover.de

1 Center of Pediatric Surgery, Hannover Medical School,

Carl-Neuberg-Str. 1, 30625 Hannover, Germany

2 Department of Pediatric Cardiology and Intensive Care, Medicine, Hannover Medical School, Hannover, Germany 